\title{
Belgeo
}

Revue belge de géographie

\section{Mobility and tourist locations. The case of Martinique Island, a French territory in the Caribbean}

Mobilité et lieux touristiques. Le cas de la Martinique, territoire français des caraibes

\section{Olivier Dehoorne and Huhua Cao}

\section{OpenEdition}

\section{Journals}

\section{Electronic version}

URL: http://journals.openedition.org/belgeo/12628

DOI: $10.4000 /$ belgeo. 12628

ISSN: 2294-9135

Publisher.

National Committee of Geography of Belgium, Société Royale Belge de Géographie

\section{Printed version}

Date of publication: 30 June 2005

Number of pages: 121-134

ISSN: 1377-2368

Electronic reference

Olivier Dehoorne and Huhua Cao, "Mobility and tourist locations. The case of Martinique Island, a French territory in the Caribbean", Belgeo [Online], 1-2 | 2005, Online since 27 October 2013, connection on 05 February 2021. URL: http://journals.openedition.org/belgeo/12628 ; DOI: https://doi.org/ 10.4000/belgeo. 12628

This text was automatically generated on 5 February 2021.

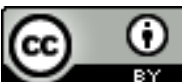

Belgeo est mis à disposition selon les termes de la licence Creative Commons Attribution 4.0 International. 


\title{
Mobility and tourist locations. The case of Martinique Island, a French territory in the Caribbean
}

Mobilité et lieux touristiques. Le cas de la Martinique, territoire français des

\section{Caraibes}

\author{
Olivier Dehoorne and Huhua Cao
}

\section{Introduction}

1 The ever-growing mobility characterizes the transformations within our societies; new relations are being established between trends and places of production and consumption. "Mobility, which is one of the central preoccupations of contemporary geography, takes many different forms including tourism and migration" (Williams \& Hall, 2002). Tourist locations are at the heart of mobility, right between the tourist flows and the varied and renewed nature of migrations. The analysis of these privileged locations enables us to highlight the growing and intense interrelations between tourist and migratory flows.

2 Migration and tourism are two components of the mobility system. Migrations remain exceptional movements and are defined by a transfer from the native residence to another location in view of a long-term settlement. This means that the migrant crosses a certain number of discontinuous thresholds and this action is defined by a "profound modification of his/her usual living area" (Thumerelle, 1986).

3 The international tourist crosses borders in the same way as an international migrant, but the motivation of the former differs: the tourist travels for pleasure, for purposes of leisure, discovery and recreation ${ }^{1}$. These movements are chosen, decided upon freely and are defined by a financial investment devoid of any professional intention, at least initially, but new projects can develop during the stay². 
During the second half of the $20^{\text {th }}$ century, tourist flows never ceased to grow, reaching 700 million international arrivals at the beginning of the $21^{\text {st }}$ century as opposed to 25 million fifty years ago. Today, international tourism concerns $11 \%$ of the world population; with narrower definitions - which take into account the leisure-oriented movements - we can reasonably consider that $6 \%$ of the world population effectively participated in international tourism in $2001^{3}$.

5 Migratory flows follow different routes: 175 million people were living outside their home country in 2000, some $3 \%$ of the world population. Between 1990 and 2000, the number of migrants in the world increased by $14 \%$, that is the equivalent of 21 million persons.

6 However, the most attractive countries have created restrictive policies: "in 2001, 44 per cent of developed countries had policies aiming to lower immigration levels, as did 39 per cent of developing countries"4. From now on the selection criteria for emigration are more strict: it is the most well-educated and well-trained that circulate with the most ease, with special emphasis on migrations between northern countries. In the context of the global free-market economy, free movement is not viewed by all in the same way: if capital, goods, information and tourists can move faster and easier, the perspectives are entirely different for workers from the least developed countries who are confronted with European and North-American "fortresses".

In the present context of the closing of the North-South borders and of intensified controls at the borders of the European Union or the USA, tourist locations are strategic points: due to the availability of employment at the margins of the richest regions, the narrow routes through which migrants can devise strategies to access tourist issuing centres. These are just some aspects which make tourist locations a privileged setting in which to pursue this reflection.

\section{The Caribbean area between migration and tourism}

\section{A plural space}

8 The interest shown in the Caribbean area is based on several considerations. Firstly, this area (some 4 million square kilometres with 300 million inhabitants) is a territorial mosaic of various contrasting statutes and living standards:

- 13 insular independent states and 16 other territories under North American and European control (France, Netherlands, the United Kingdom) and more than a dozen continental states.

- there are huge discrepancies in the GDP per capita; from 1 to 42, the extremes being the Cayman Islands (more than 21,000 \$ per capita in 2000) and Haiti (510 \$). The richest territories: the American (16,890 \$/capita) and British (14,210 \$/capita) Virgin Islands, the Bahamas (14,960 \$) and Martinique (14,360\$) are neighbours of independent states in difficulty, such as Jamaica $(2,610)$, the Dominican Republic $(2,130)$ or Honduras $(920)$. 
Figure 1. The Caribbean.

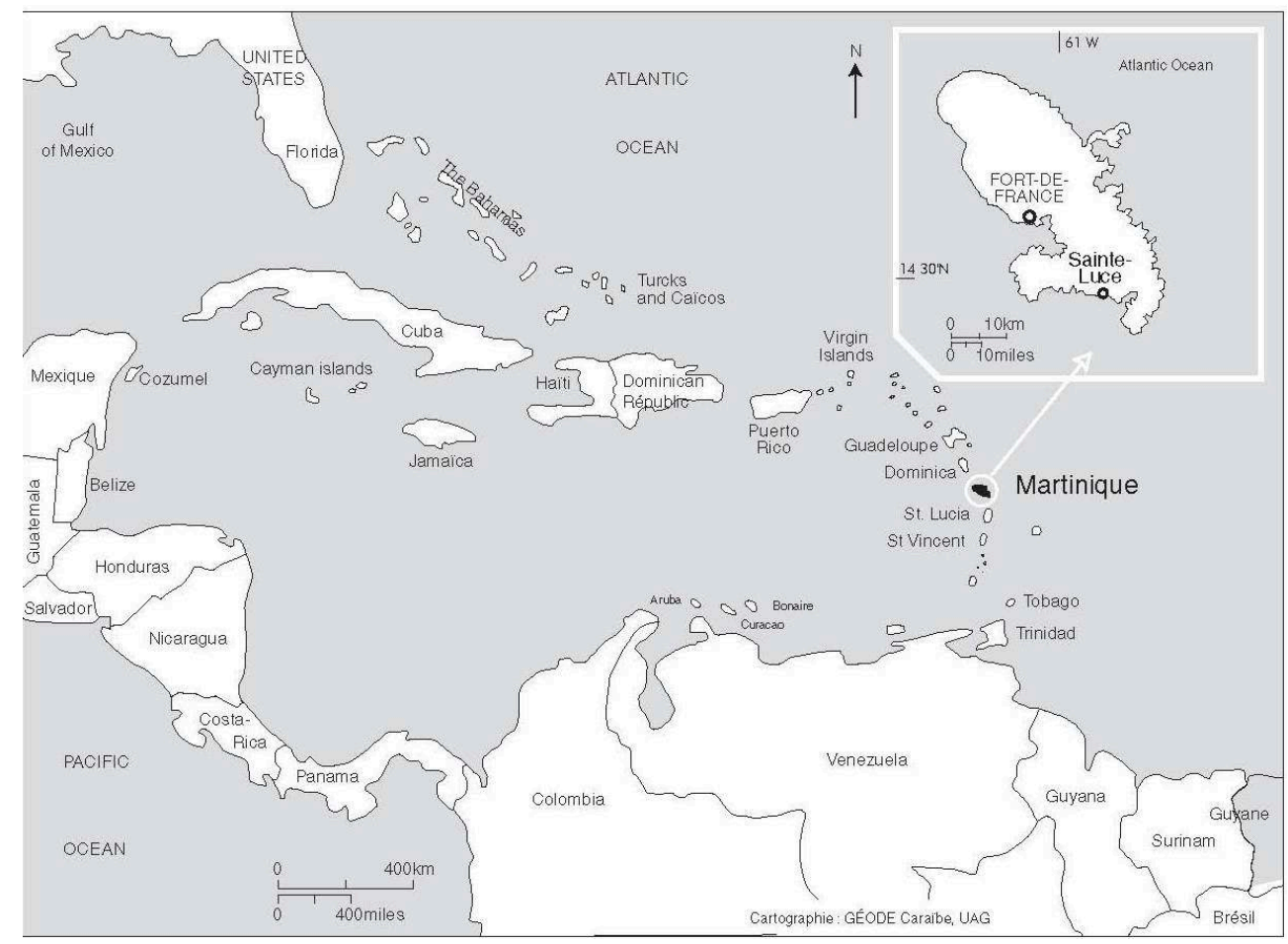

9 These situations differ from one territory to another and account for the intensity of migratory flows in this torn and divided area where income from tourist activity is fundamental to the economy of many islands. Besides the intensity of tourism in microterritories, this region, which is a border between Europe and America, is crossed by the continental and maritime North-South border, fragmented with intermediary tourist islands - sometimes closed or even "reserved" between North and South. With all these elements, the Caribbean provides us with a rich laboratory within which we can ponder on the mobility system.

The disparity in the standards of living remains fundamental to understand the internal migrations such as toward Miami, which has the appearance of a capital of the Caribbean (Audebert, 2000). The urban area of Miami counts nearly a million people originating from Caribbean islands. Migrants also leave regional spaces toward the dominant metropolises of North America (New York, secondarily Toronto, Montreal) and Europe.

Bond privileges link some island territories (former colonies or current dependencies) to Paris and London and work conventions with determined duration associate Englishspeaking territories (like Jamaica, Trinidad and Tobago, Guyana) with Canada.

Outgoing flows are characterized by their recent and considerable character (taking into account the volume of population of the area). Political contexts (departures of Cubans in the years 1960-1970), wars (in Central America in the years 1980-1990), or the deliquescence of the States left to the mercy of armed gangs (Haiti) are as many additional reasons which cause these migrations. These migrants belong to the middle class as well as to the most desperate populations. The role of economic liberalization should equally be stressed. The elites deposit their money in Florida and New York, Miami being the first banking place of the Caribbean. These elites enjoy at least two main residence places: in Miami and in their country of origin. 


\section{Complexification of the migratory diagrams} leading to an increase in poverty (Pellegrino, 2000) involve more diversified migrations, including of skilled workers (in particular in the English-speaking islands like Trinidad), such as the most impoverished who sometimes merge with asylum seekers. The future is rather seen within foreign countries, within the networks of the community installed in the metropolises of the North. It is in this context that in the 1990s a significant tourist economy established gradually in some privileged territories (Barbados, the Bahamas, Saint Martin, Puerto Rico...). Tourism represents an internationalization of the island economies which open up to the space of globalization. Tourism does not stop emigration flows, but on the contrary will intensify mobility in the Caribbean basin: in addition to the arrival of tourists in growing numbers, the international companies make certain categories of (skilled) workforce move, and other intra-regional, non official flows, are established toward tourist locations.

The opening of the territories and the renewal of the economies starting from the privileged territorial enclaves involve the incoming of new migrants external to the Caribbean area. The island character of some territories (a strong reality in the past) becomes relative in front of the progression of the new information and communication technologies. Satellite television, the extension of internet, the remote management of bank accounts, the quality of the telephone links, not forgetting the efficiency of air transport, are as many elements which make it possible to remain in relation with one's place of origin. Consequently, thanks to the close relations throughout the world, the settlement of new populations becomes easier in some of these Caribbean territories. 
Figure 2. The place of tourism in the economy of the Caribbean.

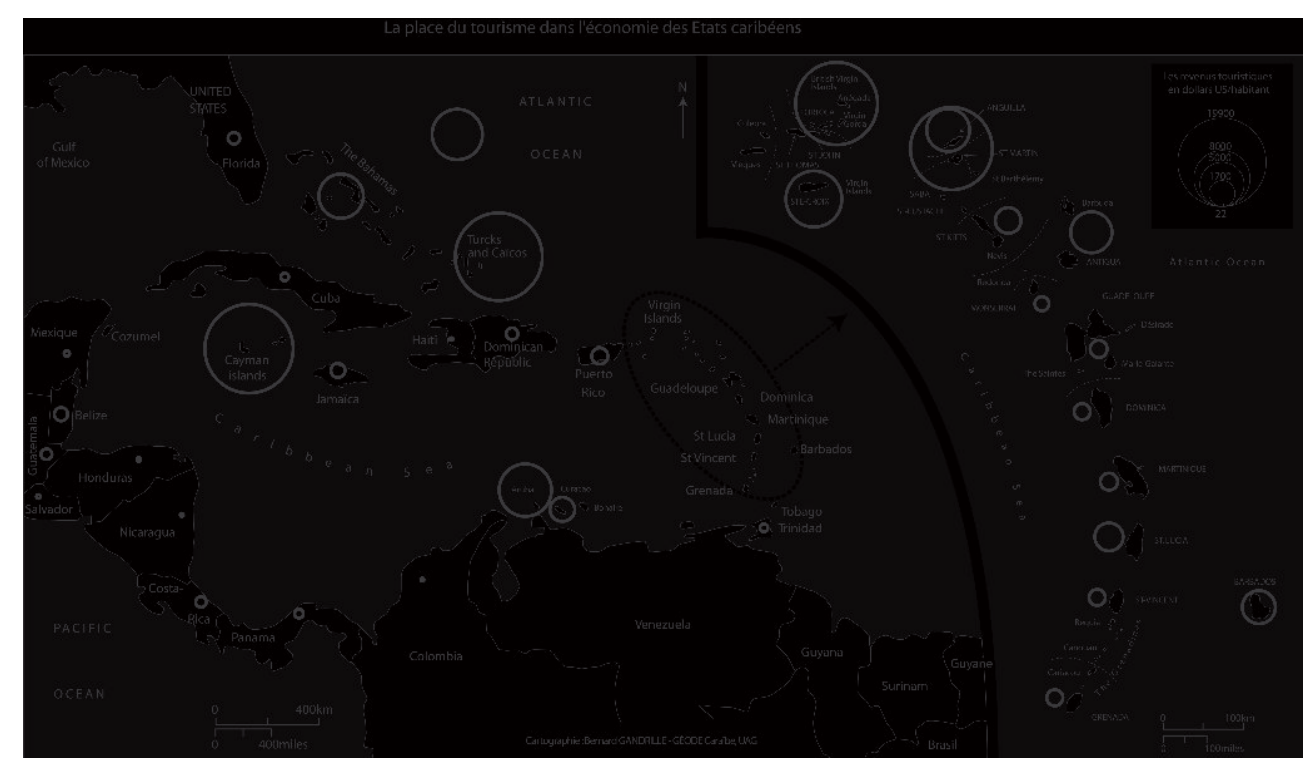

\section{Tourism and migration: interrelation and filiation}

17 The analyses carried out in tourist places stress the increasing association of more objectives which constitute the major motivation: the economic opportunity and the choice of a new living area, "working on the beach", "living and working on a tropical island", the choice of another way of life. These new migrations no longer meet economic demand; they are largely encouraged by the will to change the living area. This category of mobility takes on a new dimension nowadays: it remains the privilege of the richest societies - although not exclusively - and reveals what we call postmigratory mobility in the globalization era.

18 The characteristics of migrants as tourists evolve, become more complex, diversify and revolve at a planetary level. The emigrant becomes a migrant; he does not pass from one sedentary action to another but develops his mobility capacity between his home and receiving country. In the same respect, tourists coming from urban and sedentary rich societies change their relationship with movement: travelling by plane is no longer exceptional. The distinction between a daily and occasional occurrence is not that simple anymore: the Balearic Islands are in close proximity to the European metropolises (Salva Tomas, 2002a; 2002b). Individuals come closer to tourist locations through more frequent movements and envision new professional strategies which would allow them to divide their time between these different places, a continuum between these different living places is taking shape (Knafou, 2000).

19 People, migrants and tourists are progressively creating for themselves unique circular territories, organized around different places which they inhabit (for a shorter or longer period during the year) based on their life experiences and spatial capital. The relationships between tourist and migratory flows are ever more complex and intense. The varied and renewed flows stimulate themselves mutually as well as the tourist locations at the heart of mobility. 


\section{The example of Martinique}

\section{A French Island in the Caribbean area} displays the institutional particularity of a former colony, which has become a French département (since 1946) and belongs today to the European space: it is financially supported by Europe and now receives flows of incoming visitors and new residents coming from the vast zone that is Europe (from France, Belgium, Germany, Bosnia). The four main categories of mobility are the following:

- migrations of autochthonous populations;

- tourist flows;

- arrival of workers coming from the outside;

- passing residents.

Martinique Island (with a surface area of 1100 square kilometres for 400000 habitants) is one of the richest islands of the region. It distinguishes itself by the presence of a local middle class, a characteristic rarely seen in the region.

full stagnation. Only $7 \%$ of the active population works in this sector (dominated by banana, pineapple, sugar cane and rum production). There is a decline in subsidized cultures and the "Sugar Island" is obliged to import sugar beet in order to meet local demand. The industry (less than $15 \%$ of the active sectors) is dominated by energy supply enterprises (starting with the oil imported to provide electricity). In these "under-influenced" and dependent economies, characterised by an "overrepresentation" of civil servants ( $70 \%$ of the actives) and endemic unemployment (30\% of the actives) supported by unparalleled social aids in the region and the common practice of undeclared employment, extreme poverty remains scarce (about 500 homeless, mostly foreign people with illegal statuses).

Euros. This sector officially hires $9 \%$ of the active population, dispersed in about one hundred hotels, holiday villages and 200 boarding houses in the country. For a few years now, tourism has undergone a crisis due to the regional competition: a transfer of investments is being carried out to the benefit of the islands which adopt the practice of social dumping (reduced duties, cheap manpower, such as in the Dominican Republic).

\section{The complexity of human flows in the Martinique Island}

4 The mobility of people from Martinique reveals contradictory movements. During the 1960 s to 1980s, the population level remained stable: the balance surplus was compensated by departures encouraged by the French government (jobs reserved in the French administration). From the 1980s, departures are less numerous (local resistance, living in the country) and return flows emerge with emigrants returning to their native island (especially due to changes within the police force, customs and post offices). Incentive policies encourage youngsters to study in France (training assistance, scholarships) but the island now has its own university and students are 
also attracted to Canada. The French Government is no longer able to control this mobility so easily and the demographic burden on the island is increasing. emigrants, who come here to reconcile work with quality of life. They often discover the area during their holidays and then decide to try their luck; they sometimes work in tourism - notably by developing all the activities which autochthonous populations refuse to carry out for the "whites". Historical disputes have not been settled, and the French authorities give priority to acquiring consensus through subsidies, but forsaking the past which remains a taboo subject. The people in this category, often childless couples (youngsters or young pensioners) in pursuit of well-being allow us to highlight the tourism migration continuum.

The presence of migrants coming from the North is reinforced by new residents, essentially civil servants and other qualified personnel, whose motivations reveal mostly economic opportunities (high salaries, fiscal advantages for pensions), even though these individuals are not insensitive to the environment. Contrary to the emigrants, residents are characterised by an important mobility in their usual practices, not only within the island but also in the region, as well as in relation to their native area. Their presence spans only a few years: there is an important short-term and medium-term turnover with departures to other islands and metropolises. Decisions to leave are determined by difficulties linked to inadequate local education and precarious medical assistance, especially for the elderly.

Circulatory logics are being shaped within the frame of a career project: youngsters gain their professional experience in different tourist locations (between the Indian Ocean, the Western African Coast and the Caribbean Sea) with an evolution in each job (more responsibility). 
Officially, the island has 6,500 European and Caribbean emigrants and some 500 clandestines (undoubtedly even more in the squats of the mangrove in Fort-de-France Bay). These figures under-estimate the reality. It is estimated that there are approximately 400 new households established every year on the island.

\section{The example of Sainte Luce: from a fishing village to a tourist resort}

31 The recent evolutions in Sainte Luce (southern sea coast of Martinique) indicate the different transformation phases of this traditional fishing village against the backdrop of the arrival of new residents: a first limited wave in the late 1960s in the old market town, along the sea front, and a second wave in the peripheral residential area since the late 1980s. The increase in land and housing costs trigger a progressive withdrawal of the autochthonous population toward new local authority housing within the territory and further up in the hills. A new spatial organisation is being established between the autochthonous population, migrants, new residents and tourists. Nighttime - and clandestine - connections link the village to the Saint-Lucia Isle, some kilometres further south, through exchanges of stolen car parts, drugs and clandestine passages.

The new territorial organisation in the village of Sainte Luce is similar to that of Martinique Island and the ensemble of Caribbean territories: between the increasingly complex nature of flows, the arrival of new populations ("displaced" local populations, emigrants, tourists, residents) and economic and political issues - often covert - which require a reflection on the meaning of international and socio-spatial frontiers of the past and present. The territory evolves toward a juxtaposition of enclaves from which the various occupants are unaware of the existence of the other groups of people, each category having its own spatial logic. 
Figure 3. Sainte Luce: from a fishing village to a tourist resort.

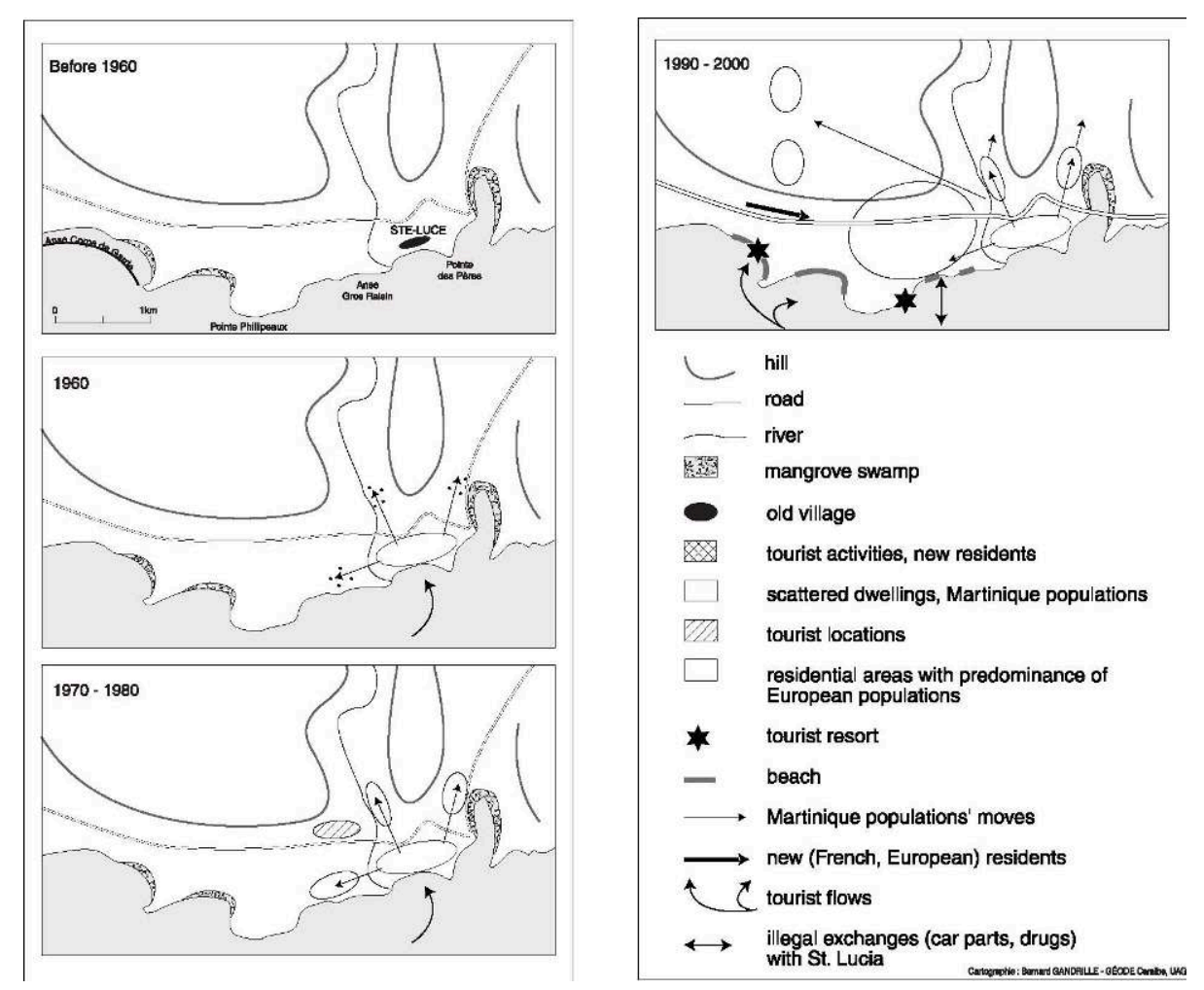

MAPPINg: BERNARD GRANDRILLE - GÉODE CARAÏBE, UAG

\section{From the Martinique Island to the Caribbean Area}

\section{A composite and fragmented Area}

The contrasts between levels of wealth are just as much frontiers which limit or prohibit human migration in the Caribbean. Tourism, the region's main resource, reinforces economic inequalities. Tourist revenues per capita go from US\$19,900 in the Cayman Islands (for a population of 35,000 persons), to US\$ 8,000 in the Virgin Islands (121,000 inhabitants), to US\$ 4,300 in Antigua and Barbuda, to US\$2,000 in Saint-Lucia, to US\$ 640 in Porto Rico and US\$ 7 per capita in Haiti.

In the British Virgin Islands (17,000 inhabitants), tourism produces $45 \%$ of the GDP and more than $25 \%$ of jobs available. In the American Virgin Islands, two thirds of the jobs are related to tourism. These cramped, barely inhabited island territories attract migrants and clandestines both as destination and transit points. A significant workforce, flexible and with no official status, finds seasonal or longer-term jobs in the tourism sector (catering, hotel-related activities and maintenance activities in general). Borders preserve tax havens, which are also the most luxurious tourist areas, while other islets are reserved for the richest customers (such as the Nevis Isles or the Mosquito Coast). Other borders tend to contain populations coming from poorer areas like the Dominican Republic, the Central American Coast and of course the stricken island of Haiti. There are also more and more departures from the close Dominican Republic, confronted with an important economic crisis in spite of the good frequentation of these tourist enclaves 5 . 
In this context tourist locations constitute privileged places: for a job or a first work experience enabling an individual to adjust to North-American society in the hope of achieving legal migration. The privileged places in this migratory strategy are the American and British Virgin Islands, the Bahamas, Saint Martin. The latter, divided between France and the Netherlands, is not actually separated by any material border. of the 36,000 inhabitants, the foreign population represents $25 \%$, divided between the people of Haiti $(60 \%)$ and the Dominican Republic (20\%). Of the 12,000 officially recorded foreigners, 5,000 are clandestine. Since the tourist crisis of the late 1990s "the hunt for clandestines" has been set in motion. Saint Barthélemy, the (tax-free) neighbouring island which receives a top-of-the-range tourism, officially has 6,800 inhabitants and 81 unemployed in 2000. The island needs a foreign workforce, i.e. those "invisible workers". These islands are important transit places for the definitive migrations to the United States.

\section{The mobility theory and the Caribbean}

Williams and Balà (2002) invite us to ponder on the "mobility concept starting from a hierachized classification of people's needs". We suggest to split the fourth and last category in two.

The first category corresponds to mobility which responds to a need for survival and individual security, and concerns the refugees and asylum seekers. Departures are made in haste, boat people move during the night and sometimes disappear out at sea (e.g., from Haiti, between extreme poverty and violence, there are mafia gangs such as the "cannibal army").

The second level is related to the flight from instability and poverty (lack of food and clothes, fulfilment of basic needs). We refer here to the migrants of Haiti, the Dominica, St-Lucia, and all the faceless and nameless people who, with only a few food reserves, go from harbour to harbour of the Caribbean Coast in the hope of being able to sneak into a container ship heading for Miami.

The third level concerns the search for a better economic and social status, the appeal of high salaries. Some migrants are more qualified; we refer here to intra-regional and international movements. They can find an employer who provides them the authorizations to work in foreign countries. But very often, confronted with the lack of legal means to leave their country, they buy forged identity papers (for example of French nationality), then join anglophone islands (St-Lucia, Antigua) while passing themselves off as French West-Indian tourists. And from these places, they buy plane tickets to go to Canada.

41 The next level corresponds to the temporary movements of consumers on holiday: tourist flows. Tourists are at the origin of financial transfers: they come to consume, not to work.

The last level is that of mobility corresponding to the choice of a new living place namely a new lifestyle: between tourism and daily leisure activities in a more favourable environment and mainly in tourist locations which welcome new residents. We refer here to the whole or partial transfer of a professional activity, in particular in the world of business, entertainment, management of the natural environment and biodiversity. This new mobility remains a prerogative of the well-off classes of rich societies and a handful of the privileged elite from the rest of the world - with a few 
exceptions. These populations are characterized by a high frequency of movements and by the fact that they have multiple dwellings (the living area is thus divided between several places: between a metropolis of north-southern America and a few privileged tourist locations in the Caribbean. This marginal mobility, which existed since the $19^{\text {th }}$ century in the area with the famous winter residences of businessmen ${ }^{6}$, is more and more developed today. If it remains the prerogative of the most well-off ${ }^{7}$, it now extends to other categories, less fortunate, with a greater variety in the geographical origins and the personal plans 8 .

\section{Conclusion} national economies and an increasing regionalization of the labour market (with unequal implications according to the islands). This economy gives place to greater intra-regional and international mobility.

The tourist locations of these areas, remote peripheries of North American and European metropolises, constitute channels of entry toward the North for migrants. Very often, these places authorize non-official migrations tacitly because the tourist companies need flexible workers, without qualification, the least heavy possible, to carry out incompressible tasks (gardening, maintenance work). And in the Caribbean basin, the transnational networks with their providers of migrants (from Colombia to Miami) orchestrate an invisible mobility which feeds the illicit activities (in relation to prostitution and drug consumption, grafted in these tourist enclaves), the best example of this being Jamaica.

Individuals with varied and complex motivations and contrasting movements converge toward tourist locations, which represent mirrors of globalisation. Movements can be made by plane, taxi or bicycle, by migrants, "fake tourists" - and true migrants -, tourists and new residents conveying the image of a world which "runs at several speeds". The analysis of mobility must take social and economic scales into account and one should reflect upon the meaning of new and old frontiers. Similar to crossroads, tourist locations are simultaneously strategic phases - temporary working places and intermediate places - for migrants who wish to reach the rich metropolises of the North. Conversely, they, in turn, also receive populations coming from the North, between holiday stay and new resident status.

46 And beyond the Caribbean case, this new mobility, complex, with multiple logics and interferences, can be observed in the Mediterranean islands and coastal areas, on the northern coast of the Philippine Islands or the coastal areas of Australia or New Zeeland. The choice of a living environment and the pursuit of present well-being prevail in the case of these post-migratory movements which characterize the new living place-workplace-tourist place continuum). 


\section{BIBLIOGRAPHY}

AUDEBERT C. (2000), "Miami, porte d'entrée de la Caraïbe aux Etats-Unis”, Terres d'Amériques, Ed. Karthala- GEODE-Caraïbes, 3, pp. 375-418.

BELL M. \& WARD G. (2000), “Comparing temporary mobility with permanent migration”, Tourism Geographies, 2, 1, pp. 87-107.

BURAC M. (1999), “L'occupation touristiques de Paradise Island (Nassau - Bahamas), Terres d'Amériques, éd. Karthala-GEODE-Caraïbes, 2, pp. 267-297.

CARLES S. (2000), "Les migrations internationales au début du XXI ${ }^{\mathrm{e}}$ siècle: tendances et problèmes mondiaux", RISS, 165, pp. 313-327.

CLAVAL P (2002), "Reflections on human mobility at the time of globalization", in MONTANARI A. (ed.), Human Mobility in a borderless world?, Rome, Società Geografica Italiana, pp. 47-68.

DEHOORNE O. (2002), “Tourisme, travail, migrations: interrelations et logiques mobilitaires", Revue Européenne de Migrations Internationales (REMI), 18, 1, pp. 7-36.

KNAFOU R. (2000), "Les mobilités touristiques et les loisirs dans le système global des mobilités", in BONNET M. \& DESJEUX D. (éd.), Les territoires de la mobilité, Paris, PUF, pp. 193-204.

MASSEY D.S., ALARCON R., HUGO G., KOUAOUCI A., PELLEGRINO A., TAYLOR J.E. (1998), Worlds in Motion. Understanding international migration at the end of the millenium, Oxford, Clarendon Press.

MONTANARI A. (2002), "Migrants, tourists and pilgrims: how to build an international comparative research in geographical sciences", in MONTANARI A. (ed.), Human Mobility in a Borderless World?, Rome, Società Geografica Italiana, pp. 29-43.

PELLEGRINO A. (2000), "Les tendances de la migration internationale en Amérique latine et dans les Caraïbes”, RISS, 165, pp. 449-462.

SALVA-TOMAS P. A. (2002a), “Tourist development and foreigner immigration in Balearic Islands”, REMI, 18, 1, pp. 87-1001.

SALVA-TOMAS P. A. (2002b), "The complex human mobility flows in the Mediterranean region: the case of the Balearic islands as phenomenon type 'new California"', in MONTANARI A. (ed.), Human mobility in a borderless world?, Rome, Società Geografica Italiana, pp. 243-258.

THUMERELLE P.-J. (1986), Peuples en mouvement. La mobilité spatiale des populations, Paris, Sedes, $325 \mathrm{p}$.

WILLIAMS A.M. \& HALL C.M. (2000), "Tourism and migration: news relationships between production and consumption”, Tourism Geographies, 2, 1, pp. 5- 27.

WILLIAMS A.M. \& BALA V. (2002), "Mobilité internationale en Europe centrale: touristes, commerçants et migrants”, REMI, 18, 1, pp. 37-65.

\section{NOTES}

1. Migrants' motivations are multiple: forced movements (urgency for survival), social (marriage, family regrouping) and economic reasons (find a better job or simply find a job), respectively to improve the quality of life. Among these migrations we also distinguish commuting (daily or weekly movements) within the usual living area. 
2. The tourist leaves temporarily his main dwelling place in order to go and live somewhere else, outside his usual living area. If he decides to stay more than three months, the visitor can no longer be considered a tourist; his knowledge of the receiving place has evolved, his consumption habits are no longer the same: he becomes a "resident", even though he has a tourist visa (Dehoorne, 2002).

3. More than $90 \%$ of international tourists belong to developed societies with high standards of living; the others, of more dispersed geographical origin, belong to the wealthiest social strata and, in the extreme cases, to some elites from developing countries, whose contribution to international tourism remains very reduced.

4. International Migration Report 2002, U.N.

5. This example poses the problem of development choices, tourist investments control, low prices of certain tourist stays. The tourist locations of the Dominican Republic, which attract the North-American middle class, and especially Europeans, pay very little from the economic point of view to the country. Gas shortage, fuel inflation, electricity cuts are the everyday life of nationals, who conceive their future only in their community emigrated and established in the United States.

6. See the text of Maurice Burac (1999) who studies the progressive occupation of the Bahamas to entertaining ends.

7. For example, a French contractor settles in Saint Barthélemy (a tax haven under French administration) to run a business in Guadeloupe and Martinique (where the standard of living and the volume of consumers allow interesting benefits). Then he hires primarily workers from St-Lucia (for an equal qualification level, the wages will be 4 times less important).

8. Like a botanical garden created by a British neo-pensioner in St-Lucia or the opening of a dancing school by Finnish nationals in Martinique.

\section{ABSTRACTS}

This paper contributes to the analysis of the mobility system through strategic sites represented by tourist locations, mirrors of globalisation. Tourist locations exist merely through human flows: varied and complex flows between migrations and tourism. In the context of North-South border control, emerging tourist locations situated at the margins of the richest regions sometimes represent an opportunity to bypass the regional borders.

Through the analysis of mobility in the Caribbean area, the previous categories used to describe the types of mobility demonstrate their limits when faced with the complexity of flows and growing interactions. Subsequently, a microanalysis of Martinique Island enables us to reflect upon the social aspects of this mobility and to ponder on the issues concerning the old and new political and socio-spatial borders.

Cet article contribue à analyser le système des mobilités à travers des lieux stratégiques que sont les places touristiques, miroirs de la mondialisation. Les places touristiques n'existent qu'à travers les flux des hommes, flux variés et complexes entre migrations et tourisme. Dans le contexte de contrôle des frontières Nord-Sud, les lieux touristiques émergents, situés sur les marges des régions les plus riches, représentent parfois une opportunité pour contourner les frontières régionales.

A travers l'analyse des mobilités dans l'espace caraïbe, les anciennes catégories utilisées pour 
décrire les types de déplacements montrent leurs limites face à la complexification des flux et les interactions croissantes. Ensuite, une microanalyse à l'échelle de l'île de la Martinique permet d'ouvrir une réflexion sur les aspects sociétaux de ces mobilités et de s'interroger sur les enjeux autour des frontières, nouvelles et anciennes, politiques et socio-spatiales.

INDEX

Keywords: tourism, migration, mobilitiy system, frontier, Caribbean, Martinique

Mots-clés: tourisme, migration, système des mobilités, frontières, Caraïbes, Martinique

\section{AUTHORS}

\section{OLIVIER DEHOORNE}

MCF Géode, Université Antilles-Guyane, dehoorneo@hotmail.com

\section{HUHUA CAO}

Department of Geography, University of Ottawa, caohuhua@uottawa.ca 